\title{
Understanding intrinsic elements from drama text with cooperative learning method type STAD
}

\author{
Yunni Damayanti ${ }^{1}$, Atmazaki ${ }^{2}$, Ngusman Abdul Manaf ${ }^{3}$ \\ ${ }^{123}$ Universitas Negeri Padang, Padang, Indonesia, (yuni26damayanti86@gmail.com)
}

\begin{abstract}
This research is done to describe the process, result and increasing factors of students' ability in understanding the intrinsic elements from drama text by using cooperative learning method type STAD of grade VIII.3 of Tri Bhakti Junior high school students Pekanbaru. The conclusion are; first, in the increasing process, teacher explain the learning target, explain the learning material, read student with the highest score to become group's chairman, teacher monitored the learning process, then students come back to their own chair and answer the questions given by the teacher. Second, the students' ability in understanding the intrinsic elements from drama text increase, from 64 in pre-cycle become 72.68 in cycle I then there is an increasing score in cycle 2 with average score 88.82 . Third, Factors cause the increasing students' ability in understanding the intrinsic elements of drama text are; chairman is responsible to the group work in order to understand the material and answer the questions related to elements of drama text that is explained, and students can explained in front of the class with good and correct language.
\end{abstract}

Keywords: drama text, intrinsic elements, cooperative method type STAD.

\section{Introduction}

In learning Indonesian language, student should mastered four skills; Listening, Speaking, reading and writing. One of the student skills in learning process is reading. Reading skill is student skill or ability in reading a text. Such as learning prose, that is covered learning short stories and novels.Learning drama coveredthe understanding the content and the elements of drama. The use of drama material can be seen in from several research related to it, among others is from Indonesia: Putra, Martono, \& Priyadi (2015), Sumarni, Effendy, \& Nadeak (2015), Amalia, \&Doyin (2015), Yusman (2017). The research result from Amalia, \& Doyin (2015), it can be conclude that, first: explaining the students and teacher' need to the construct a short story guidebook. Based on the analysis result from the students and teachers' need, they want the presentation from the structure of constructing a short story' guidebook entitled The Guideline of Constructing a Short Story. Second, formulated the principles from constructing a short story'guidebook with intrinsic element technique. The result applied in language varieties. Third, describe the prototype from the development of constructing a short story' guidebook with intrinsic element technique for junior high students. The result, the consistency principle and the relevancy is drawn in graphic in this book. 
Sumarni, Effendy, \& Nadeak (2015) research result is the description of character and the development of protagonist's character in dwilogy novel of Blues Merbabu and 65 Gintayani's work that tell about the history's influence of G.30 SPKI in the development of mentality and journey of life from the protagonist. The result from the research based on the analysis of dwilogy novel of Blues Merbabu and 65 Gintayani's work, it can be conclude that the data analysis'result shows that the character from the protagonist does not like to be curbing with rules that can limit his freedom. The result from his character's development, he is very relaxed in live the life but he has the purpose to be the best by rich his knowledge and learn from the past experience.

Putra, Martono, \& Priyadi (2015), done the research "Increasing understanding ability of intrinsic elements from drama text by using cooperative learning method type STAD of grade VIII B State Junior High School 19 Pontianak school year 2015/2016". From this research result, can be conclude that the learning result of understanding ability of intrinsic elements from drama text by using cooperative learning method type STAD is increase. The research result from the students group work's cycle I in understanding the intrinsic elements of drama text is 74 in average score. In cycle II, result from the students group work in understanding the intrinsic elements of drama text reach 83.1 in average score.

Basically the learning of drama is very interesting, because we can engage the students to be active especially in doing a drama. However, it is the part that students feared of because they feel clumsy and shy in doing drama. And the impact, it makes the students cannot answer questions related to drama correctly. This is what happened in the process and the learning result from the grade VIII. 3 of Tri Bhakti Junior high school students Pekanbaru school year 2017/2018.

Based on the observation, students cannot answer the question related to drama correctly. It is because of some reasons, for example students do not know well about drama, they still rarely watch drama, and students rarely practice the drama. The students' inability in answering the question related to dramastill not yet accommodated wel. In the class, teacher still use discourse method and question answer method in learning drama. The use of electronic media was very low, it made the students did not know about drama, they just imagined it.

From the problems faced by the students in learning drama, it can be said that it become the teacher's job to make the drama lesson become more interesting. The method that is usually used might be made the students feel that learning drama is not interesting. The method that probably more suitable is STAD (Study Teams-Achievement Divisions). STAD is one of the simplest cooperative learning methods i.e. starting from class presentation, group quiz, individual development score, and group recognition. It is proved from several research results, such as from Arab ArabBalfakih , Naqib, (2003); from Indonesia Hariadi, Wurjianto, (2016); Astuti, (2014); Ferina, (2015), Thomas, (2015), from Iran Zarei, (2012), from Pakistan Majoka, Hukam, Mahmood, (2010).

STAD method requires the students to make group presentation. Then, after group presentation, quiz is given to the students in individual. Therefore, students have their individual score besides their group score. In this case, students' group work is playing drama.But, before students start playing drama, to let them know about drama, teacher show to the students about drama that the theme related to students' daily life so the students know how to do role play.

This research's tittle is almost the same as Erniwati (2011) which is talking about the intrinsic elements of drama text. There are different in the research, the objective of Erniwati (2011)research is increasing the result of using cooperative learning type STAD in grade VIII.3 State Junior High School 11 Pekanbaru. The process is increase. In pre-cycle score, students who pass the standard score only 2 students or $5.0 \%$ from 40 students. In cycle 1, students who pass the standard score become 11 students or $27.5 \%$. Then in cycle II all of the students pass $100 \%$. 
Erniwati (2011) done this research to identified the intrinsic elements of drama text by using cooperative learning model tyoe STAD of grade VIII.3 State Junior High School 11 Pekanbaru, the result of the research done by the researcher also want to find the intrinsic elements of drama text (theme, background, plot, character, and the message). Erniwati's research (2011) also done in two cycle; cycle I and cycle II. So, the different from this research and Erniwati's research (2011) is about the result and the support factors in understanding the intrinsic elements of drama text.

The use of STAD method is a method that makes students more active and interesting about the drama lesson. Therefore, the use of this method is to make the students feel interesting in learning drama, students will easier to understand it. In the end, the students will be able to answer question related to intrinsic element of drama text. It is make researcher feel interesting to do this research entitled "Increasing ability of understanding the intrinsic elements ofdrama text by using cooperative learning method type STAD of grade VIII.3 of Tri Bhakti Junior high school students Pekanbaru'.

\section{Method}

Research about increasing ability of understanding the intrinsic elements of drama text is categorized into classroom action research with qualitative data processing. This research is done in Tri Bhakti Junior high school students Pekanbaru. This research is done in August up to October 2017. The subject of this research is all of the students in grade VIII.3 Tri Bhakti Junior high school students Pekanbaru or about 35 students.

This research is done in two cycles. Before doing cycle I and II it will be explained the condition of pre-cycle. Pre-cycle activity is an activity where the students conventionally in answer questions related to drama text before using cooperative learning method type STAD in the class. In cycle I, activities done by the researcher is to take score by using cooperative learning method type STAD, but students still take the score in individual. The activities done in STAD method; first, teacher explains about the leaning target. Second, researcher presents the information/ material. Third, researcher read the students pre score to group the students. Forth, researcher always guides the students during the learning process, and monitored inactive students in doing their work. Fifth, after the group work was finished, students asked to come back to their own sit and do some task in individual. Cycle II, the activities were similar as cycle I. Researcher still used steps in cooperative learning method type STAD. The activities done in cycle II; first, researcher read the students score from cycle I and asked the highest score to stand in front of the class and received a reward. Second, researcher explained the learning target. Third, researcher asked the students to come back to their previous group in order to answer the question given by the researcher together. Forth, researcher was still monitored every group. Students were very enthusiast to answer the question read by group 7. Group 7 get the lowest score, which is whyresearcher asked the group to step forward in front of the class. Fifth, researcher asked the students to come back to their own sit and answer the question given in individual.

The data of the research is a result of observation from the classroom action research and student activities' observation in learning process. Besides, this research data is the result of an interviewed about the implementation of understanding the intrinsic elements of drama. This research data also the result score of essay test about understanding the intrinsic elements of drama.

\section{Results and Discussion}

Pre-cycle was the phase that was done before implementing the use of cooperative method type STAD in the process of understanding the intrinsic elements of drama text in cycle I and II. In this pre-cycle, researcher was make interaction to the students and collaborate the target to know more about every students' character. Researcher tries to control the classroom to create a comfortable atmosphere during the learning process. Researcher explained the material and example about drama 
spontaneously during the learning process and give chance to the students to practice drama in order to make students feel enthusiast in learning process.

The implementation process and the increasing result in cycle I. Cycle I is done in two meetings; in September 13th and October 2nd 2017 in grade VIII.3 Tri Bhakti Junior high school students Pekanbaru. In the first meeting, researcher explained to the students about the material in drama that is difficult to understand.Students are still confused in determining the theme, plot, characterization and the message. Researcher has tried to carry out the learning activities as well as possible, and there is anincrease that already good enough. But there is some students still do not pass the standard score. Next, explained some points during the implementation of cycle II. Cycle II is done in October 5th 2017 in grade VIII.3 Tri Bhakti Junior high school students Pekanbaru. This meeting attended by a collaborator and did not make the students feel unconfident. In this cycle II, researcher gave opportunity to group $\mathrm{G}$ to stand in front of the class, because they get the lowest score. Researcher asked the group $\mathrm{G}$ to be more active, even there were only 3 students in the group.

The implementation process and the increasing result in cycle II

In cycle I, still found there are some students who do not understand the intrinsic elements of the drama text. Researcher still tried to for an increase in the next meeting (cycle II) in order to make change in answering the questions. This is the guidance that is done by the researcher during the learning processs in cycle II.

This cycle II, there was a considerable increase. Because, in every elements there is an increase from pre-cycle, cycle I and cycle II. Even there are some students that answer the theme elements, plots, and characterization still in general. The activity did not affect the increase of intrinsic elements of drama texts from pre-cycle to cycle II.

Researcher divide students into groups based on the students' initial score's result. The student who scored the highest score, choose as the group leader to help his friends in the group. Teacher asked group 1 to set an example to another group and explain it by using STAD method. Group 1 begins their activities as the chairman of ADT and explained to the groups and cooperating each other, so that the other groups will pay more attention. In the end, teacher gave examples of drama textentitled "Rough People"to the students to be answered the intrinsic elementsof it. Researcher monitoredevery activities and scold students who did not work and learn.

This class action research has been carried out according to the plan that has been prepared before. The collected data is then analysed according to the research needs. This research was done in two cycles. The full results of each cycle are clearly described in this chapter. The condition of the students' learning result in pre-cycle shows the ability of the students to understand the intrinsic elements of the drama text by assessing 5 aspects; theme, background, plot, characterization, and the message. From 35 students, there are only 9 peoplewho reached KKM score or $(25.71 \%)$ with an average of 64 . Details made from each element, understand the theme element is $51 \%$, understand the background element is $70 \%$, understand the plot element is $52 \%$, understanding the characterization element is $72 \%$, and understanding the message element is $73 \%$.

There are still some students who do not understand the intrinsic elements in pre-cycle. Researcher tried to guide the students in order to make them increase in the next meeting (cycle I, and cycle II), alsoto make changeswhen answering questions. This guidance is carried out by the researcher during the learning process, for example Alfitois not realy understand the elements of theme and plot. In the theme element Alfito answered the title of drama text. He assumed that the theme is in the title. The guidance that done by researcher; first, give an example of a drama video. Because with this video will make the students easy to understand the theme because it can be seen directly the drama video, second,researcheraskedAlfito to understand definition of theme, thirdresearcher asked Alfitoto read drama texts and mention orally one by one what is being 
discussed in the drama "Fogging" so that, the closest answer is researcher asked to be answered/ written without helping the student. Next, on the students who do not understand the other intrinsic element.

Based on the final results from the implementation of the action it can be seen from the final test of understanding the Intrinsic elements of Drama textby assessing 5 aspects; understanding the intrinsic element of theme, background, plot, characterization and the message, from 35 students, only 14 students who got KKM score or $40 \%$ whereas there are 21 students or $60 \%$ who failed. Here are the details made with each element; understand the themeelement is $67 \%$, understand the background elementis $80 \%$, understand the plot element is $74 \%$, understand characterization elementis $76 \%$, understand message element is $77 \%$.

There are still some students who do not understand the intrinsic elements in drama text. It can be seen from one of the students follow; Erwin still cannot answer the question related to theme correctly. Guidance done by the researcher; first, researcher asked Erwin to answer definition of the problems theme in the drama text. Researcher asked the students to answer one by one about the theme from drama text "SimpulTerurai". If it already answered, researcher asked the students to make conclude the problem closest to the title, and write it on the answer sheet. It different from the pre-cycle, Erwin answered the message element completely. In cycle I, he did not answer it completely; it made the decrease in the message element from pre-cycle to cycle I. The guidance that researcher done is remind Erwin thatmessage is a message/ moral value contained in the drama text that must be answered completely. Those are guidance done to the students during the cycle I to cycle II.

Based on the final results of the final action in cycle II, it can be seen from the final test in understanding the intrinsic elements of the drama text individually by assessing 5 aspects; understanding the theme element (85\%), background (93\%), plot (83\%), characterization (89\%), message $(80 \%)$. from 34 students there are only 32 students or $94.11 \%$ who reach the KKM score, whereasthere are 2 students or $5.88 \%$ who failed.

Table 1. Students Average Score Per-Indicator in Pre-Cycle, Cycle I, Cycle II

\begin{tabular}{ccccc}
\hline No & & \multicolumn{3}{c}{ Average } \\
\cline { 3 - 5 } & & Pre-Cycle & Cycle I & Cycle II \\
$\mathbf{1}$ & Theme & 51 & 67 & 85 \\
$\mathbf{2}$ & Background & 70 & 80 & 93 \\
$\mathbf{3}$ & Plot & 52 & 74 & 83 \\
$\mathbf{4}$ & Characterization & 72 & 76 & 89 \\
$\mathbf{5}$ & Message & 73 & 77 & 80 \\
& Total Score & 318 & 374 & 430 \\
& Average Total Score & 63.6 & 74.8 & 86 \\
\hline
\end{tabular}

\section{Conclusions and Recommendation}

Based on research findings and discussion it can be concluded that (1). After doing the research, there is an increased ability in understanding the intrinsic elements of drama text. The things done by the researcher are (first) Teachers explained the purpose or the learning target. The aim is to motivatethe students about what learning objective that should be achieved on that day. The second process was the researcher present/ explained information about the material on that day. Researcher 
explainedit by using electronic media such as infocus, speaker, and laptop. Third after the teacher explained it, the researcher read the students' pre-cyclescorein order to construct group learning. Groups were formed randomly by researcher based on student score. Students are first given an individual test. After that, the highest scorefrom each student is chosen as the leader in the group.Four, researcher guide the group work and study. Researcher monitoredlearning progress from each group. Fifth, after the discussion finished,researcherexplained to the students to come back to their sit, and then the researcherevaluatethe learning process. Students are given a drama text entitled "SimpulTerurai". Students are instructed to answer the intrinsic elements of the text individually.

There is an increasing score in understanding the intrinsic elements of the drama text. As follows; the average score of pre-cycleis 64 to 72.68 in cycle I, after thatthere is increase in cycle II with average score 88.82 .

Factors contribute the increase of ability in understanding the intrinsic elements of drama text are as follows:

1. The team leader guided his friends until they can understand the material that is being taught.

2. Each group tried to perform well by using good language to present in front of the class.

3. Each group is responsible for their own group in order to answer questions from the other groups.

This result supports the previous research conducted by Erniwati (2011), entitled the use of STAD method in learning can increase the student activity learning process and the student score.

\section{Recommendation}

Based on the conclusion above, researcher suggeststhe teachers to use cooperative learning method type STAD in learning process in the classroom. Because it makes students more active and responsible in the group, it makes the students try to compete in term of understanding the material that is being taught, and compete to reach the highest score for their group.

\section{Acknowledgments}

In this occasion, the author would like to express his greatest gratitude to the mentor who has helped author to complete this journal. To Prof. Dr.Atmazaki, M.Pd, as mentor I who has given knowledge and advice, guidance, encouragement, and time in order to complete this journal. To Dr.Ngusman Abdul Manaf, M. Hum as the mentor II, that has given knowledge, advice, and his patience in order to complete thisjournal. The authors hope that this journal can be useful for all parties, especially for those who read it.

To the headmaster who has given the opportunity and time to the researcherin order to take data at Tri Bhakti Junior High School in Pekanbaru.

To Meyranti, S.Pd, as the collaborator who has helped, guide the researcher in the implementation of this activity for 3 months and spend time in the learning process during the class.

To all students of Tri Bhakti Junior High School, especially students of grade VIII.3 who have participated in the implementation until completion. 


\section{References}

Arikunto, Suhardjono, Supardi. (2011). Penelitiantindakankelas. Jakarta: BumiAksara.

Hasanuddin,WS. (2009). Drama karyadalamduadimensi. Bandung: Angkasa

Hayati, A., \&Masnur, M. (1990).Latihanapresiasisastra: penunjangpengajaranbahasadansastraindonesia. Surabaya: Triana Media.

Padmodarmaya, P. (1990). Pendidikanseniteater: buku guru sekolah das ar.Jakarta: DepartemenPendidikandanKebudayaan.

Priyatni, E. T. (2012). Membacasastradenganancanganliterasikritis.Jakarta: BumiAksara.

Slavin, R. E. (2005).Cooperative learning: teori, riset, danpraktik. Bandung: Nusa Media.

Trianto.(2012). Mendesain model pembelajaraninovatif- progresif.Jakarta: Kencana

Astuti, Y. P. (2014). The use of student team-achievemen division (stad)to improve the students' reading comprehension practice. English Education Journal.(EEJ). 4(1)

Bakri, Y. (2017). Penerapan model pembelajaran kooperatif tipe stad untuk meningkatkan kemampuan membaca dalam memahami isi cerita pendek pada siswa kelas VSDN 25 ampanayusman. Jurnal Kreatif Tadulako Online Vol. 4 No. 4 ISSN 2354-614X

Ferina, F. (2015). Stad as a strategy of teaching reading comprehension in junior high school.JEELS.5.(1), 15.

Majoka, I. M.. (2010). Student team achievement division (stad) as an active learning strategy: emprical evidence from mathematics clasroom. Journal Education and Sociology.

Naqib, M. A. (2003). The effectiveness of studen team-achievement division (stad) for teaching high school chemistry in the united arab emirates. International Journals Of Science Education. 5.(25), 605-62

Thomas, A. D. (2015). Effect of computer-assisted stad, ltm and icicooperative learning strategies on nigerian secondary school students'achievement, gender and motivation in physich. Journal of Education and Practice. 6(19)

Zarei, A. A. (2012). The effects of Stad and Circ on L2 reading compreherension and vocabulary learning. Frontiers of language and teaching. 3. 